УДК 167.7-37.025“313”159.9-057.4

DOI https://doi.org/10.32689/maup.psych.2021.2.4

\title{
Тетяна КОРЕНЬ
}

аспірантка, Класичний приватний університет, вул. Жуковського 70-б, м. Запоріжжя, Україна, 69002 ORCID: 0000-0002-3918-0454

\section{Tetiana KOREN}

Graduate Student, Classical Private University, 70-b Zhukovsky str., Zaporozhye, Ukraine, 69002

ORCID: 0000-0002-3918-0454

\section{МОДЕЛЬ ПСИХОЛОГІЧНОГО СУПРОВОДУ ПРОФЕСІЙНОГО РОЗВИТКУ МАЙБУТНЬОГО ПСИХОЛОГА У ВНЗ}

\author{
MODEL OF PSYCHOLOGICAL SUPPORT \\ OF THE FUTURE PSYCHOLOGIST PROFESSIONAL \\ DEVELOPMENT IN HIGHER SCHOOL
}

У статті розроблено модель психологічного супроводу, яка сприяє формуванню умов для професійного розвитку психологів; визначено особливості психологічного супроводу: напрями, приниипи, рівні, види; зазначено критерії оцінювання ефективності психологічного супроводу. На різних етапах професійного розвитку психологів у ВНЗ неминуче виникають психологічні проблеми, зумовлені змістом і особливостями процесу професійно-особистісного самовизначення. Позитивну роль у подоланні изих проблем, досягненні вериин самореалізачії може відіграти комплексний психологічний супровід прочесу професійного розвитку, який необхідно здійснювати з опорою на особистісний потенціал студента. У статті вивчено особливості технології психологічного супроводу: його напрями, принципи, рівні, види; визначено критерії очінювання ефрективності психологічного супроводу майбутніх психологів. У підсумку автор статті зазначає, шуо створена модель психологічного супроводу в контексті роботи психологічної служби буде ефективно реалізована на практиці, оскільки ияя інноваційна технологія дає змогу істотно збагатити процес професійної підготовки майбутніх психологів.

Ключові слова: психологічний супровід, модель психологічного супроводу, психологічна служба ВНЗ, професійний розвиток майбутнього психолога.

The article develops a model of psychological support, which contributes to the formation of conditions for professional development of psychologists; features of psychological support are determined: directions, principles, levels, types; the criteria for evaluating the effectiveness of psychological support are indicated. At different stages of professional development of psychologists in universities, psychological problems inevitably arise due to the content and features of the process of professional and personal self-determination. A positive role in overcoming these problems, reaching the peaks of self-realization can play a comprehensive psychological support of the process of professional development, which must be carried out based on the personal potential of the student. The article examines the features of the technology of psychological support: its directions, principles, levels, types; criteria for evaluating the effectiveness of psychological support for future psychologists are defined. As a result, the author of the article notes that the created model of psychological support in the context of psychological services will be effectively implemented in practice, as this innovative technology allows to significantly enrich the training of future psychologists.

Keywords: psychological support, model of psychological support, psychological service of the university, professional development of the future psychologist.

Актуальність проблеми. Нові соціальні вимоги, позв'язані з упровадженням у систему вищої освіти України положень Болонського процесу, який орієнтує ії на більш ефективне використання своїх ресурсів, вимагає і перебудови системи підготовки психологів у сучасних умовах задля досягнення іiі якісно нового рівня.

У свою чергу, існуюча сьогодні нагальна потреба в психологічних знаннях вимагає підвищення вимог до якості освіти психологів, що знайшло своє відображення у прикладних дослідженнях О. Бондаренка, В. Ляудіс, Е. Романової, В. Семиченко та ін. Однак поза увагою дослідників залишилися питання зміни діяльності психологічної служби відповідно до підготовки майбутніх психологів у ВНЗ.

На різних етапах професійного розвитку психологів у ВНЗ неминуче виникають психологічні проблеми, зумовлені змістом і особливостями процесу професійно-особистісного самовизначення. Позитивну роль у подоланні цих проблем, досягненні вершин самореалізації може відіграти комплексний психологічний супровід процесу професійного розвитку, який необхідно здійснювати 3 опорою на особистісний потенціал студента. 
Отже, однією із спроб подолання цієї проблеми $\epsilon$ впровадження в освітній простір особистісно орієнтованої освіти (В. Давидов, О. Деркач, Ю. Забродін, В. Зінченко, та ін.), впровадження компонентів психологічної підтримки (Л. Газман, I. Дубровіна, С. Кривцова, та ін.), допомоги, захисту (О. Власова, Ю. Савенко, А. Штипель та ін.), супроводу (Г. Бардиєр, М. Бітянова, Н. Обухова, та ін.).

Одним із засобів реалізації ідей особистісно орієнтованої освіти й надання дієвої допомоги в створенні умов для повноцінного розвитку психолога $є$ психологічна служба, в якій повинна реалізовуватися модель психологічного супроводу. На наш погляд, саме організація психологічного супроводу в процесі навчання дасть змогу оптимізувати процес підготовки психологів, які відповідатимуть сучасним вимогам.

У дослідженнях останніх років феномен психологічного супроводу, став предметом наукового осмислення. Саме в цьому напрямі інтенсивно йде розробка нових освітніх і психологічних технологій, спрямованих на розвиток особистості.

Однак аналіз наукових досліджень дає підстави констатувати, що залишається нез'ясованим питання про те, наскільки можливий в умовах вузівського навчання психологічний супровід професійного розвитку студента-психолога, які механізми психологічного супроводу при цьому можуть бути використані, і які його критерії ефективності. Також є невизначеною роль психологічної служби у вирішенні цих завдань.

Один з напрямів пошуку пов'язаний із розробкою концептуальних основ функціонування психологічної служби ВНЗ, діяльність якої буде здатна вирішувати завдання психологічного супроводу студентів у професійному розвитку. Все це й визначає актуальність нашого дослідження.

Визначення мети дослідження. Метою статті $\epsilon$ розробка моделі психологічного супроводу, яка сприятиме формуванню умов для професійного розвитку психологів.

Згідно 3 метою дослідження було поставлено такі завдання: 1) вивчити особливості технології психологічного супроводу: його напрями, принципи, рівні, види; 2) визначити критерії оцінювання ефективності психологічного супроводу майбутніх психологів.

Виклад основного матеріалу дослідження. У вітчизняній психолого-педагогічній літературі супровід розглядається як різновид процесу навчання й виховання. Аналіз сучасної психолого-педагогічної літератури показує, що існує неоднозначне бачення місця й ролі психологічного супроводу [4].
Відповідно до цього, відсутнє чітке його розуміння. В одних випадках його відносять до основних видів роботи психолога й чітко визначають його роль і місце [2], в інших взагалі не згадують при аналізі змісту діяльності психологічної служби ВНЗ [4].

Ми вслід за Е.Ф. Зеєром розглядаємо психологічний супровід як цілісний процес вивчення, формування, розвитку й корекції професійного розвитку особистості. При аналізі професійного розвитку особистості в період навчання можна говорити про психологічний супровід як про системоутворювальний вид діяльності практичного психолога в системі психологічної служби ВНЗ.

Спираючись на визначення психологічного супроводу і грунтуючись на різних підходах до розуміння його сутності, розглянемо основні положення. Для цього ми визначимо мету, завдання, функції, принципи, види психологічного супроводу майбутнього психолога.

Метою психологічного супроводу в системі освіти є створення в межах об'єктивного психолого-педагогічного простору умов для максимального особистісного й професійного розвитку. Основним завданням психологічного супроводу професійної підготовки майбутніх психологів $є$ допомогти студентові стати повноцінним суб'єктом свого професійного життя [4].

Психологічний супровід сприяє створенню орієнтовного поля професійного розвитку особистості, формуванню професійного Я, підтримці об' єктивної самооцінки, оперативній допомозі й підтримці, саморегуляції життєдіяльності, освоєнню технологій професійного самозбереження.

Таким чином, психологічний супровід особистості є безперервним процесом ви- вчення, формування й удосконалення особистості в межах освітнього простору, який вбачається нами найпродуктивнішою технологією підвищення якості освіти. Високоефективність цієї технології зумовлюється функціями, які вона виконує: діагностичною, цільової орієнтації, планування, організаторською, мобілізаційно-спонукальною, комунікативною, формувальною, контрольно-аналітичною й оцінювальною.

Для реалізації цих функцій у психологічному супроводі необхідно додержуватися таких принципів: відкритості; коректності, дотримання психологічних вимог щодо підтримки комфортних умов взаємодії - доброзичливість, моральне й емоційне заохочення, чуйність; орієнтації на професійну взаємодію; орієнтації на здатність студента самостійно долати труднощі; конфіденційність 
(анонімність); безперервність; мультидисциплінарність (комплексність).

На наш погляд, системоутворювальною ознакою необхідності процесу психологіч- ного супроводу $є$ характер суперечності між наявністю в людині проблеми і його Я. Необхідно враховувати, що в процесі супроводу присутні два суб' єкти (ключові фігури): носій проблеми (супроводжуваний) і той, хто допомагає вирішити проблему (супровідний). Спрямованість взаємодії, таким чином, буде визначати різні види психологічного супроводу.

Розділяючи психологічний супровід на види, ми беремо за основу класифікації такі критерії: 1) часовий простір (попередження виникненню проблеми, навчання супроводжуваного методам вирішення проблем у процесі розв'язання проблемної ситуації, екстрена допомога у кризовій ситуації (Є. Казакова)); 2) тип впливу (індивідуально орієнтований й системно орієнтований);

3) суб'єкт (супровідний: викладач, психолог); 4) за змістом (комплексний, тематичний або локальний, параметричний); 5) за частотою (періодичний, постійний).

Наведена класифікація дає змогу розглянути сукупність ознак, які характеризують психологічний супровід, але вона не вичерпує різноманіття ситуацій того, хто супроводжує. Незалежно від виду психологічного супроводу, усі вони пов'язані зі співчуттям, співпереживанням, співробітництвом, які допомагають особистості на шляху саморозвитку [3].

Психологічний супровід професійного розвитку студентів-психологів може бути ефективним, якщо він відповідає цілям, завданням цього розвитку, проводиться систематично в рамках діяльності психологічної служби ВНЗ за такими напрямами:

1) розробка й реалізація програми індивідуального супроводу з урахуванням створення більш сприятливих умов для розвитку суб'єктів супроводу; 2) створення профілактико-корекційних програм, спрямованих на подолання проблем, характерних для майбутніх психологів.

Супровід є цілісною системою і як будь-яка система складається 3 елементів або компонентів, які водночас $\epsilon$ його інваріантними етапами: діагностики, що служить основою для постановки цілей; відбору й застосування методичних засобів; аналізу проміжних і кінцевих результатів, що дає можливість корегувати хід роботи.

Ми пропонуємо виділити два рівні організації психологічного супроводу: теоретичний i емпіричний. Теоретичний рівень забезпечує безперервність, системність, цілісність процесу психологічного супроводу за допомогою єдиної логіки розвитку майбутнього психолога. Емпіричний рівень передбачає його системну організацію всередині кожного етапу: цільову спрямованість, зміст підтримки, педагогічні умови, технологію, проміжні й кінцеві результати, етапи психологічного супроводу (підготовчий, первинна діагностика, первинна допомога, повторна діагностика), індивідуального супроводу (консультативно-методичний, підсумкова діагностика).

У процесуальному плані супровід можна описати через послідовну реалізацію таких етапів: 1) проведення кваліфікованої діагностики сутності проблеми, її історії й потенційних сил їі носіїв; 2) інформаційний пошук методів, фахівців, які можуть допомогти вирішити проблему; 3) обговорення можливих варіантів вирішення проблеми з усіма зацікавленими суб'єктами й вибір найбільш доцільного шляху вирішення;

4) надання супроводжуваному первинної допомоги на початкових етапах реалізації плану (М. Бітянова, М. Семаг, Е. Казакова та інші).

Відповідно до етапів психологічного супроводу виділимо три основні компоненти, які не можуть існувати окремо, усі вони взаємопов'язані між собою.

Перший компонент - систематичне відстеження психолого-педагогічного статусу студента 3 погляду його актуального стану й перспектив найближчого розвитку. Другий компонент - створення соціально-психологічних умов для успішного навчання й розвитку «психологічного благополуччя» студентів. Третій компонент - створення спеціальних соціальнопсихологічних умов для вирішення проблем навчання, спілкування й психічного стану конкретних студентів або академічної групи [4].

Аналізуючи концептуальні положення психологічного супроводу, ми можемо визначити його предмет - процес спільного зі студентом визначення його власних інтересів, цілей, можливостей і шляхів подолання перешкод (проблем), що заважають йому самостійно досягати бажаних результатів у навчанні, саморозвитку, професійному розвитку, спілкуванні, способі життя.

Отже, у процесі надання психологічного супроводу необхідно допомогти студентові побачити життєву лінію як послідовність i широту рухів до поставленої мети, виробити в нього «продуктивну розумову позицію». Цього, на наш погляд, можна досягти шляхом переходу від операційно-технічних аспектів діяльності до потребнісно-мотиваційного аспекту на «рефлексивному» й «особистісному» рівнях (П. Гальперін, І. Семенов, С. Степанов). Такий підхід допоможе майбутнім психологам вже в період навчання у 
ВНЗ вирішувати не тільки поставлені перед ними в навчальній діяльності завдання, а й активізуватися в ситуації пошуку, навчитися вирішувати суперечності й здійснювати усвідомлений вибір. Процес психологічного супроводу активізується не тільки системою зовнішніх стимулів (вимог, очікувань, можливостей), а й, насамперед, системою внутрішніх спонукань: прагненнями, переконаннями, інтересами, установ- ками самої особистості, потребою в саморозвитку.

Назвавши основні концептуальні положення, визначимо основні засоби, які ми передбачаємо використовувати в реалізації психологічного супроводу: діагностичний інструментарій (бесіда, інтерв'ю, спостереження, пихобіографія тощо); групові форми роботи (організаційно-діяльністна гра (ОДГ), тренінги, семінари тощо); індивідуальні форми (консультації, корекційні методи тощо).
Ефективність реалізації моделі психологічного супроводу професійного розвитку студентів-психологів ми можемо визначити згідно 3 критеріями (результатом супроводу): сформована професійна модель психолога, здатність до самоосвіти, самоорганізації, самопрезентації, професійне самовизначення, самоствердження, професійна ідентичність, самореалізація на рівні професійного навчання.

Висновки. Ефективність процесу психологічного супроводу професійного розвитку майбутніх психологів забезпечує комплекс умов: побудови й впровадження в практику моделі й технології, що забезпечує професійний розвиток майбутніх психологів.

Ми передбачаємо, що створена модель психологічного супроводу в контексті роботи психологічної служби буде ефективно реалізована на практиці, оскільки ця інноваційна технологія дає змогу істотно збагатити процес професійної підготовки майбутніх психологів.

\section{1. Битянова М.Р. Работа с ребенком в образоватура:}

1. Битянова М.Р. Работа с ребенком в образовательной среде: решение задач и проблем развития : науч.-метод. пособ. для психологов и педагогов. Москва : МГППУ, 2006. 96 с.

2. Зеер Э.Ф. Психология профессий : учебное пособие для студентов вузов. Москва : Мир, 2006. $336 \mathrm{c}$.

3. Крылова Н.Б. Формирование культуры будущего специалиста. Москва : Высшая школа, 1990. $136 \mathrm{c}$.

4. Овчарова Р.В. Психологическое сопровождение водительства. Москва : Изд-во Института психиатрии, 2003. 319 с.

\section{References:}

1. Bityanova, M.R. (2006). Rabota s rebenkom v obrazovatel'noy srede: reshenie zadach i problem razvitiya: nauch.-metod. posob. dlya psikhologov i pedagogov. [Work with the child in the educational environment: the decision of problems and problems of development: a scientific method. allowance. for psychologists and teachers]. Moscow: MGPPU, 96 p. [in Russian].

2. Zeer, E.F. (2006). Psikhologiya professiy: uchebnoe posobie dlya studentov vuzov [Psychology of professions: a textbook for university students]. Moscow: Mir, 336 p. [in Russian].

3. Krylova, N.B. (1990). Formirovanie kul'tury budushchego spetsialista [Formation of the culture of the future specialist]. Moscow: Higher School, 136 p. [in Russian].

4. Ovcharova, R.V. (2003). Psikhologicheskoe soprovozhdenie voditel'stva [Psychological support of leadership]. Moscow: Publishing house of the Institute of Psychiatry, 2003.319 p. [in Russian]. 